DOI 10.22363/2312-9220-2019-24-1-103-108

UDC 654.19(075.8)

BBK 76.031

\title{
Challenges to the mediatization of religion in Russia: towards a normative model
}

\author{
V.M. Khroul \\ Lomonosov Moscow State University \\ 9 Mokhovaya St., bldg. 1, Moscow, 125009, Russian Federation
}

\begin{abstract}
Examining the development of religious media in Russia for last decades, author states low academic interest to this field of study and finds two main challenges to religious media. The first is deeply rooted in the post-communist religiosity - mostly nominal than practicing, the second challenge is caused by low impact of religious values on Russian media system in general and Russian TV in particular. Values dialogue faces three general problems: a) lack of values consensus, b) lack of religious selfarticulation and c) low level of social dialogue in the public sphere. Supporting British scholar $\mathrm{N}$. Couldry's call to the models of normative debate, author proposes a normative model of religious institutions and media professionals dialogue optimization, based on "pluralism - dialogue consensus" concept of J. Habermas. The proposed model is focused on the basic principles of transparency and availability of the well-articulated religious values in a public sphere and presumes certain expectations from the religious institutions and media professionals. If "operationalized" from theoretical level to practical empirical indicators, the model could serve as a tool, matrix, check-list for the evaluation of the present condition for dialogue between religion and media in particular society.
\end{abstract}

Keywords: religious media, mediatization of religion, Russia, religious identity, public dialogue, consensus, normative model

\section{Introduction}

The historical analysis of the religious media in Russia explicitly shows two stages: a) rapid development of all religious media (1990-1997) and b) their stratification after the division in 1997 into so-called "traditional" (Orthodox, Muslim, Jewish and Buddhist) and "non-traditional" (Catholic, Protestant, Hindu, new religious movements and others). The most "traditional" Orthodox media enjoyed were favored by the state (on national and regional levels), some of "non-traditional" religious media decided to choose the strategy of "self-silencing".

The research domain of journalism and communications follows the mainstream and does not pay much attention to religious media in the context of the wider public sphere. The few existing books, dissertations and papers in Russia fit into four mainstreams of research:

(1) content oriented studies (coverage of, attention to, accents, proportions, overexposure and marginalization, etc.) [1;2];

(2) institutional oriented studies (the media of Orthodox, Catholic, Protestant, Muslim, Jewish organizations) [3; 4]; 
(3) channel oriented studies (press, radio, TV, Internet, mobile networks) [1; 5];

(4) media policy oriented studies (media co-regulation, ethical issues, profanation of sacrum, scandals, dysfunctions causing conflicts, etc.) [6;7]. This stream of religious media in stricto senso is very low profiled because of the very small object of the study.

The paper analyzes main challenges for the development of religious media in Russia from the perspective of the values dialogue optimization.

\section{Voice in the wilderness: religions vs media in ethical perspective}

The current situation on Russian TV is a permanent source of concern for many people in Russia, often expressed publicly in media and academic discourse [20; 21]. But the initial public debate about the necessity of institutional social control over Russian TV programs was raised by religious organizations and then supported by other groups of civil society. Social control means social processes by which the behavior of individuals, groups or social institutions are regulated according to normative models of expected accountability. Social control, as such, is an essential instrument for the maintenance of social order and for ensuring the mutual accountability of social institutions.

A Public Council for Morality on TV was proposed by the Club of Orthodox Journalists in November 2007 and its launching finally failed in 2010. The main point of voices "contra" was a "phobia" of the renewal or rebirth of strong ideological control over media endured in the USSR [7]. Within the frames of public debates over the idea for Public Council for Morality, the major objections refer to practical questions, while the main obstacles significantly complicating the essence and sense of future activity of the council have not been articulated yet. Surely the presence of obstacles in such a society as Russia's calls the principles of establishing such a council problematic. There is a set of problems that seem significant in the analysis of the possibility of realization of the "Public Council for Morality on TV" project.

1. Axiological problem: values consensus in Russian society. In a multi-normative society in which different values and normative models caused by poly-confessional and polyethnic social structure coexist and which would be affected by other factors of diversity, the activity of any council for morality would be successful only if there would be a critical level of agreement of what is "good" and what is "bad".

2. Evaluative problem: silent religions. Religions should be the main participants of social dialogue in the moral sphere accumulating and articulating value judgments rooted in fundamental normative models (such as of Torah, the Bible, Qur'an, etc.) used in different situation of modern practice and activity. The problem is that there is no system of "moral monitoring" of events and phenomena of social life in media and public sphere made by Russian religious leaders. Even the voice of the most powerful of sources and opportunities and theoretically the most united community in modern Russia - the Russian Orthodox Church (ROC) - is not heard regularly and systematically. The Church gives estimations in an ad hoc manner - when some scandalous and extremely immoral thing happens. As it was, for instance, with the "The Last Temptation of Christ" film release, with the concert of pop-singer Madonna crucifying herself on a cross, "Pussy Riot” punk prayer in Moscow Cathedral, etc. 
There is no regular production and distribution of morally evaluated judgments of TV production and wider enunciation of diverse socially significant problems and situations made by the ROC. Moreover, as a former press officer of the ROC, priest Vladimir Vigilyanskiy, said that the Moscow Patriarchate did not plan to establish the structures for regular moral evaluation of cinema and TV production like ones created by Roman Catholic Church. Meanwhile at the Catholic Bishops Conference in the USA and in some Catholic countries there are special institutions constantly monitoring of cultural life (primarily monitoring the film and television industry) and publishing list of the main events and news of this or that sphere with reviews every week. From time to time Muslim leaders also publish the texts of normative and value contents - fatwa - actualizing dogma in the social sphere. The aim of such an activity on the field of TV consumption is to support believers in making decision of what is worth seeing and what is not. These cases might also be found in other religions.

"Today Russian society wants to hear the Church voice on some sharp and crucial questions, actual for every citizen. Such as corruption, the legitimacy of the parliamentary elections, social instability, ethnic tensions. Effectiveness of public participating in combating social ills, such as alcoholism and drug addiction. Both society and the journalistic community wait some honest, poignant and even undiplomatic answers from the Church. The readiness of the Church to such open discussion will determine the degree of credibility to the Church", - suggested Zhosul [8. P. 12].

3. Communicative problem: corrupted social dialogue. If the moral monitoring of current events and facts does have a place, if "leading light" works properly it would be possible to speak about an articulated dialogue of value systems within the framework of constructing a normative model. In particular communication about moral norms and their implementation for codifying facts and events in society is a fundamental and necessary condition for formation of a balanced broadcasting policy.

Finally, after examining religious media in Russian context, we found out that the mediatization of religion here faces 1 ) ignorant to ethics and social accountability media practitioners, 2) normatively disoriented audience with low level of media literacy and religious practice and 3) predominantly secular public sphere with problems in social dialogue processing.

\section{Normative turn: towards a common good}

The recent tensions between religions and media professionals brings us towards the elaboration of the normative model of the interaction. As British scholar Nick Couldry mentioned during the International Communication Association conference in Seattle (22-26 May, 2014), the ethical emptiness of mainstream media "calls to the models of normative debate".

Supporting this call for "normative turn", we suggest that there is a time to rediscover the principles of the religions-journalists dialogue optimization focused on the basic principles of transparency and availability of the well-articulated religious values in a public sphere. The proposed normative model presumes certain expectations from the religious institutions and media professionals at all three stages (pluralism - dialogue consensus, see table). 
The normative model of religious institutions and media professionals dialogue optimization

\begin{tabular}{|c|c|c|}
\hline & RELIGIOUS INSTITUTIONS & MEDIA PROFESSIONALS \\
\hline Pluralism & $\begin{array}{l}\text { - try to ensure values transparency, availability } \\
\text { of texts representing their normative models; } \\
\text { - seek correct articulation of their values, use } \\
\text { adequate symbolic systems, language and } \\
\text { cultural codes }\end{array}$ & $\begin{array}{l}\text { - try to present complete spectrum of values } \\
\text { and normative models (with respect to } \\
\text { minorities); } \\
\text { - optimize channels and information flows }\end{array}$ \\
\hline Dialogue & $\begin{array}{l}\text { - tolerate and respect to other value systems } \\
\text { and normative models they are not agree with; } \\
\text { - use the framework of common cultural code; } \\
\text { - participate actively in the dialogue, send } \\
\text { experts to the public sphere }\end{array}$ & $\begin{array}{l}\text { - organize and support the search for new } \\
\text { subjects of the dialogue, present new models } \\
\text { in mass communication space; } \\
\text { - mediate, moderate, create forums for } \\
\text { discussions; } \\
\text { - expand - quantitatively and qualitatively - } \\
\text { the space for dialogue in various forms of } \\
\text { communication }\end{array}$ \\
\hline Consensus & $\begin{array}{l}\text { - are seeking the common good; } \\
\text { - are optimizing the "preaching", the } \\
\text { presentation of the religious values from the } \\
\text { perspective of consensus }\end{array}$ & $\begin{array}{l}\text { - consider consensus to be one of the most } \\
\text { important goals of journalism; } \\
\text { - are peacemakers during conflicts and } \\
\text { tensions; } \\
\text { - develop professional solidarity }\end{array}$ \\
\hline
\end{tabular}

This model, if "operationalized" from theoretical level to practical empirical indicators, could serve as a tool, the check-list for the evaluation of the present condition for dialogue between religious institutions and media professionals.

(C) Khroul V.M., 2019

This work is licensed under a Creative Commons Attribution 4.0 International License

\section{References}

[1] Kashinskaja L.V., Lukina M.M., Resnianskaja L.L. (Eds.). (2002). Religija v informacionnom pole rossijskih SMI [Religion in Russian mass media information field]. Moscow: MGU Publ.

[2] Khroul V. (2012). Religion and Media in Russia: Functional and Ethical Perspectives. LAP Lambert Academic Publishing.

[3] Amialchenia A. (2014). Christian Media After Socialism: Major Trends // Khroul V. (Ed.). Religious Impact on Journalistic Cultures. Moscow: Lomonosov Moscow State University Publ. Pp. 16-20.

[4] Luchenko K. (2015). Orthodox Online Media on Runet: History of Development and Current State of Affairs in Digital Icons: Studies in Russian, Eurasian and Central European New Media. No. 14. Pp. 123-132.

[5] Zhukovskaya E. (2016). The Russian Orthodox Church in the Media Sphere: Information Management // Khroul V. Christianity in Media: Central and Eastern European perspective. Moscow: Lomonosov Moscow State University Publ. Pp. 9-16.

[6] Luchenko K. (2007). Pravoslavnyi Internet: Spravochnik-putevoditel' [The Orthodox Internet: Guidebook]. Moscow: Izdatel'skii Sovet Russkoi Pravoslavnoi Tserkvi.

[7] Khroul V. (2010). Initiatives of TV Ethics Control by Religions in Russia: Challenges for the Implementation // Religion in Eastern Europe. Vol. XXX. No. 1.

[8] Zhosul E. (2014). Orthodox Christianity and Mass Media after Socialism // Khroul V. (Ed.). Religious Impact on Journalistic Cultures. Moscow: Lomonosov Moscow State University Publ. Pp. 9-13.

[9] Ivanitsky V. (2011). Modernizaciya zhurnalistiki. Metodologicheskii etud [Modernization of Journalism: A Methodological Study]. Moscow: MGU Publ. 


\title{
Article history:
}

Received: 13 September 2018

Revised: 15 September 2018

Accepted: 28 September 2018

For citation:

Khroul V.M. (2019). Challenges to the mediatization of religion in Russia: towards a normative model. RUDN Journal of Studies in Literature and Journalism, 24(1), 103-108. DOI 10.22363/23129220-2019-24-1-103-108

\section{Bio note:}

Khroul Victor Mikhailovich, Associate Professor at the Department of Sociology of Mass Communications, Journalism Faculty, Lomonosov Moscow State University, Associate Professor at the Department of Mass Communications, Faculty of Philology, Peoples' Friendship University of Russia (RUDN University), co-chair of the Religion and Communication Qorking Group in the International Association for Media \& Communication Research.Contacts: e-mail: amen@ mail.ru

\section{Вызовы медиатизации религии в России: в поисках нормативной модели}

\author{
В.М. Хруль \\ Московский государственный университет имени М.В. Ломоносова \\ Российская Федерация, 125009, Москва, ул. Моховая, д. 9, стр. 1
}

Рассматривая развитие религиозных СМИ в России за последние десятилетия, автор констатирует низкий исследовательский интересе к этой области и анализирует две основные проблемы религиозных СМИ. Первая глубоко укоренена в особенностях посткоммунистической религиозности - преимущественно номинальной, чем практической, а вторая проблема связана с низким влиянием религиозных ценностей на российскую медиасистему вообще и на российское телевидение в частности. Ценностный диалог в стране сталкивается с тремя общими проблемами: а) низкий уровень ценностного согласия; б) низкий уровень артикуляции религиозных ценностей и в) низкая культура публичного диалога. Поддерживая призыв британского ученого Н. Коудри к выдвижению и обсуждения нормативных моделей, автор предлагает нормативную модель оптимизации диалога религиозных институтов и СМИ на основе концепции «плюрализм - диалог - консенсус» Ю. Хабермаса. Предлагаемая модель ориентирована на основные принципы прозрачности и наличия четко сформулированных религиозных ценностей в общественной сфере и предполагает определенные ожидания от религиозных учреждений и журналистов. Операционализация модели до уровня эмпирических индикаторов могла бы стать инструментом, матрицей, контрольным списком для оценки нынешнего состояния диалога как между религией и СМИ, так и общественного диалога в целом.

Ключевые слова: религиозные СМИ, медиация религии, Россия, религиозная идентичность, общественный диалог, консенсус, нормативная модель 


\section{Список литературы}

[1] Религия в информационном поле российских масс-медиа / под ред. Л.В. Кашинской, М.М. Лукиной и Л.Л. Реснянской; МГУ имени М.В. Ломоносова, факультет журналистики. М., 2002.

[2] Khroul V. Religion and Media in Russia: Functional and Ethical Perspectives. LAP Lambert Academic Publishing, 2012.

[3] Amialchenia A. Christian Media After Socialism: Major Trends // Khroul V. (Ed.). Religious Impact on Journalistic Cultures. Moscow: Lomonosov Moscow State University, 2014. Pp. 16-20.

[4] Luchenko K. Orthodox Online Media on Runet: History of Development and Current State of Affairs in Digital Icons: Studies in Russian, Eurasian and Central European New Media. 2015. No. 14. Pp. 123-132.

[5] Zhukovskaya E. The Russian Orthodox Church in the Media Sphere: Information Management // Khroul V. Christianity in Media: Central and Eastern European perspective. Moscow: Lomonosov Moscow State University, 2016. Pp. 9-16.

[6] Лученко К. Православный Интернет. Справочник-путеводитель. М.: Издательский Совет РПЦ, 2006.

[7] Khroul V. Initiatives of TV Ethics Control by Religions in Russia: Challenges for the Implementation // Religion in Eastern Europe. 2010. Vol. XXX. No. 1.

[8] Zhosul E. Orthodox Christianity and Mass Media after Socialism // Khroul V. (Ed.). Religious Impact on Journalistic Cultures. Moscow: Lomonosov Moscow State University, 2014. Pp. 9-13.

[9] Иваницкий В.Л. Модернизация журналистики. Методологический этюд. М.: Изд-во МГУ, 2010.

\section{История статьи:}

Дата поступления в редакцию: 13 сентября 2018

Дата принятия к публикации: 28 сентября 2018

\section{Для цитирования:}

Khroul V.M. Challenges to the mediatization of religion in Russia: towards a normative model (Вызовы медиатизации религии в России: в поисках нормативной модели) // Вестник Российского университета дружбы народов. Серия: Литературоведение. Журналистика. 2019. T. 24. № 1. C. 103-108. DOI 10.22363/2312-9220-2019-24-1-103-108

\section{Сведения об авторе:}

Хруль Виктор Михайлович, кандидат филологических наук, доцент кафедры социологии массовых коммуникаций факультета журналистики Московского государственного университета имени М.В. Ломоносова, доцент кафедры массовых коммуникаций филологического факультета Российского университета дружбы народов, сопредседатель рабочей группы «Религия и коммуникация» Международной ассоциации исследователей медиа и коммуникаций. Контактная информация: e-mail: amen@mail.ru 